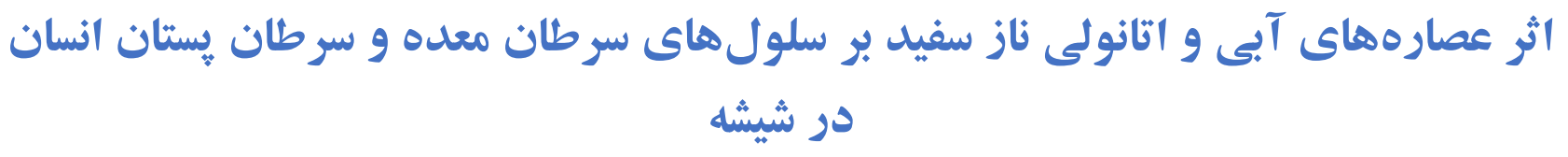

\author{
كتايون ميمندى و محملمهلى يعقوبى

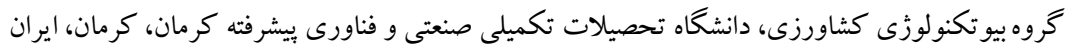 \\ مسئول مكاتبات: محمدمهدى يعقوبى، m.yaghoobi@kgut.ac.ir
}

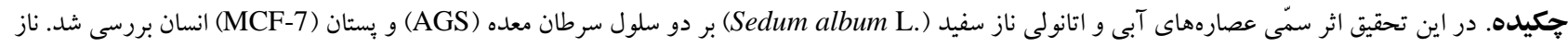

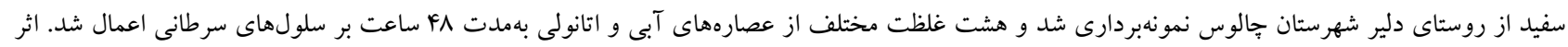

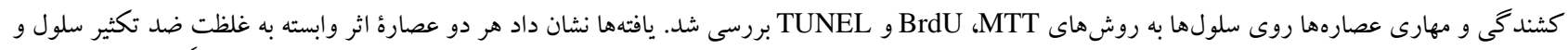

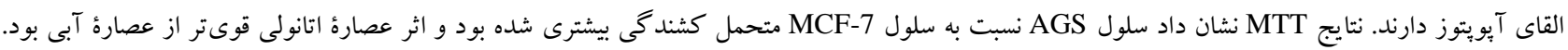

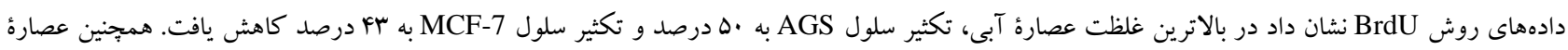

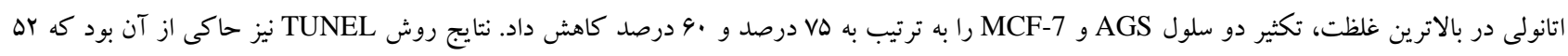

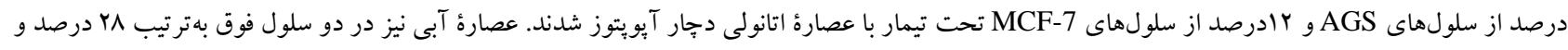

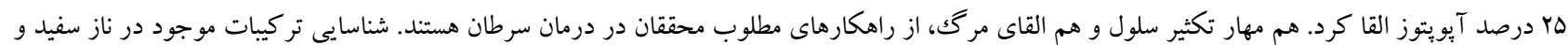

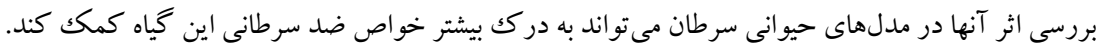
وازههاى كليدى. آيويتوز، تكثير سلول، تيرة كلنازيان، كوئرستين، كياهان ضد سرطان

\title{
The effect of aqueous and ethanolic extracts of Sedum album L. on human stomach and breast carcinoma cell lines in vitro
}

\author{
Katayoon Meimandi \& Mohammad Mehdi Yaghoobi \\ Department of Biotechnology, Graduate University of Advanced Technology, Kerman, Iran \\ Correspondent author: Mohammad Mehdi Yaghoobi, m.yaghoobi@kgut.ac.ir
}

\begin{abstract}
In this study, the cytotoxic effects of aqueous and ethanolic extracts of Sedum album L. on human stomach cancer cell line (AGS) and breast cancer cell line (MCF-7) were evaluated by MTT, BrdU and TUNEL assays. The results demonstrated that both extracts had antiproliferative and apoptotic effects in a dose-dependent manner. The MTT assay data revealed that the AGS cell underwent more cytotoxicity in comparison with the MCF-7 cell. It also revealed that ethanolic extract was more potent than aqueous extract. The BrdU assay results showed that the proliferation of AGS and MCF-7 cells was reduced to 50\% and 43\%, respectively, at the highest concentration of the aqueous extract. In addition, the ethanolic extract reduced the proliferation of AGS and MCF-7 cells to $75 \%$ and $60 \%$, respectively. The AGS and MCF-7 cells underwent 52\% and 12\% apoptotic death upon treatment by the ethanolic extract as TUNEL assay showed. The aqueous extract induced 28\% and 25\% apoptosis in the AGS and MCF-7 cells, respectively. Both inhibition of proliferation and induction of apoptosis are desirable strategies for cancer treatment among researchers. Identification of $S$. album compounds and analyzing their effects in animal model of cancer can help us with understanding its anti-cancer properties.
\end{abstract}

Keywords. anticancer plants, apoptosis, cell proliferation, Crassulaceae, quercetin 
هوايى اين گياه كوئرستين و سه گليكوزيد فلاونول ايزورامنتين جدا شدهاند (Wolbis, 1989).

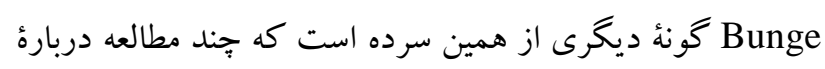

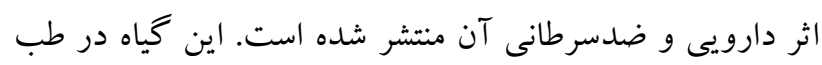

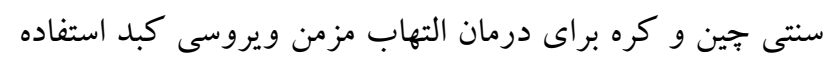

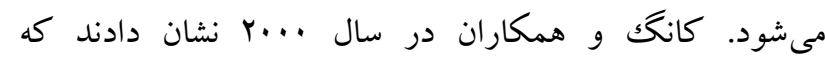
آلكالوئيدهاى كياه Sarmentosum كبد موشى و انسانى اثر ضد تكثيرى دارند. آلكالوئيدهاى اين كياه با مهار تكثير سلولهاى سرطان كبد باعث تجمع آنها در فاز

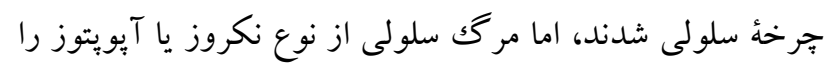
القا نكردند (Kang et al., 2000).

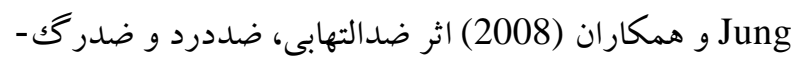

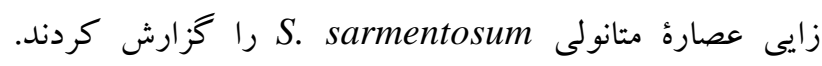

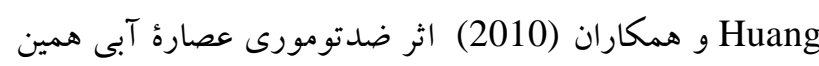
كونه را بر سلولهاى تومورى كبد انسان HepG2 كزارش

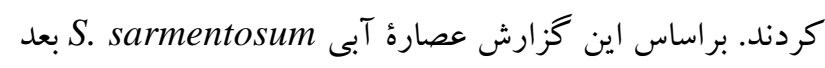

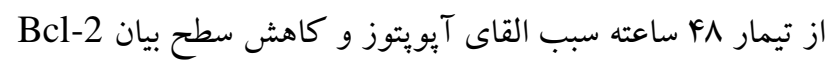

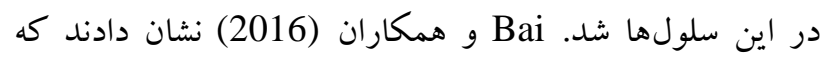

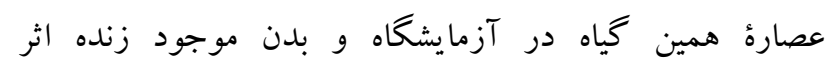

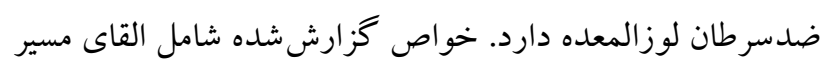

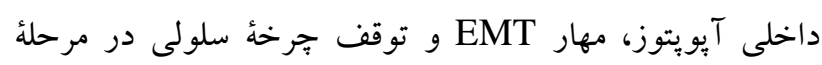
G2/M

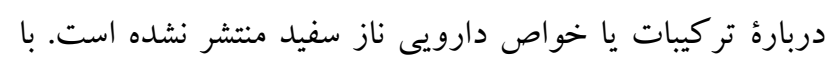

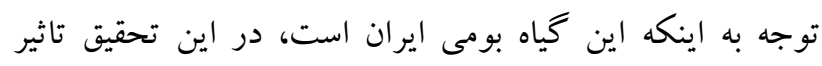
عصارة آن بر سلولهاى سرطانى انتخاب بررسى شده است.

\section{مواد و روشها}

\section{جمع آورى نمونهها}

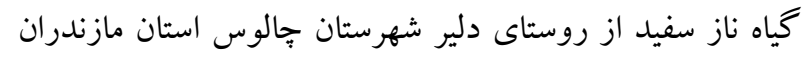

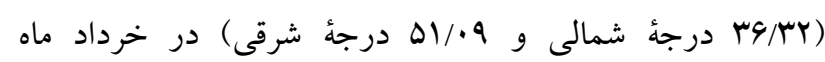

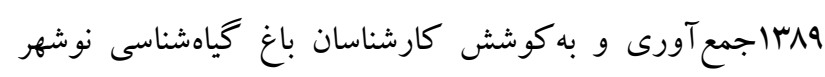

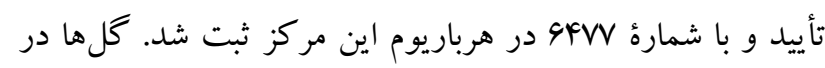

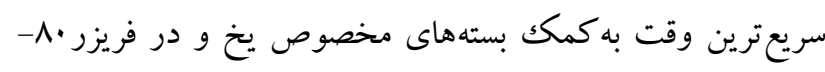
درجه سانتيخر اد نخههارى شدند.

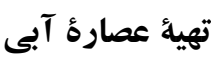

براساس گزارش سازمان جهانى بهداشت، در بين عوامل اصلى

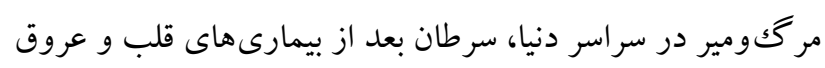

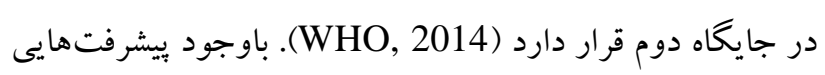

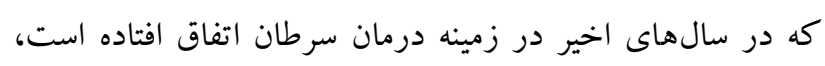

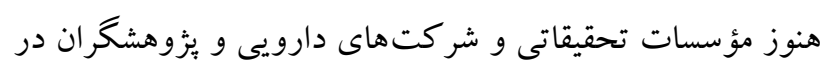

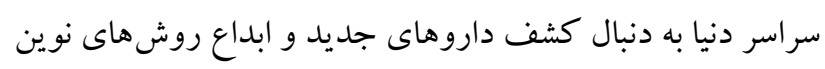

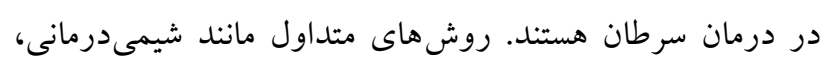

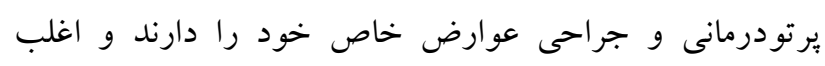

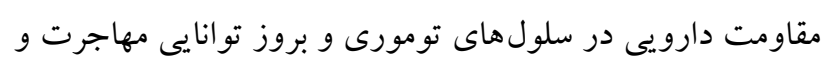

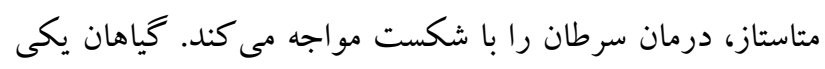

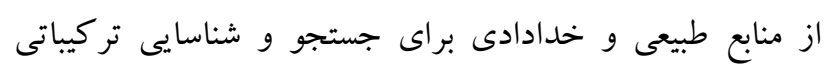

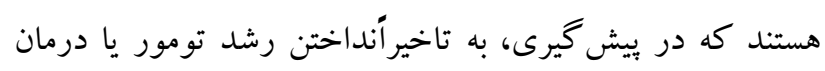

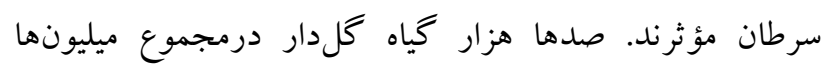

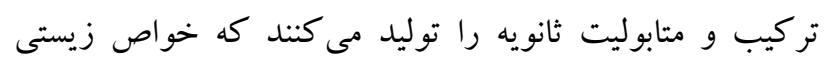
بسيارى از آنها ناشناخته است. اين منبع عظيم طبيعى براى شناسايى داروهاى جديد همواره هدف توجه محققان بوده است.

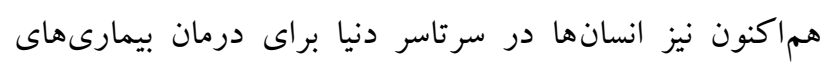

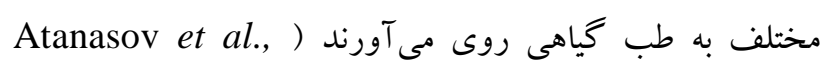
2015; Ouyang et al., 2014; Tariq et al., 2017; Zhou جالب توجه است كه نزديك به ه V درصد از (et al., 2016 ). داروهاى تأييدشده جهانى در درمان سرطان از گياهان و منابع

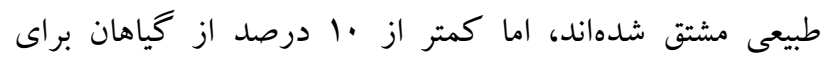

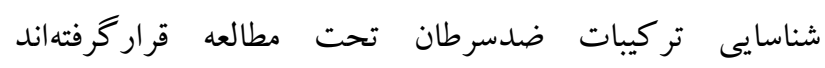
(Newman \& Cragg, 2016) خياهان جديد و مطالعهنشده براى شناسايى اثرها و تركيبات احتمالى ضدسرطان احساس مى شود.

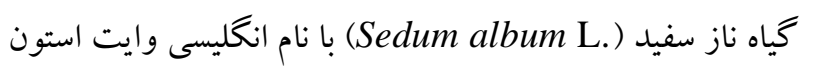

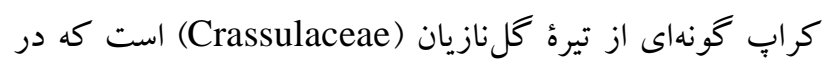

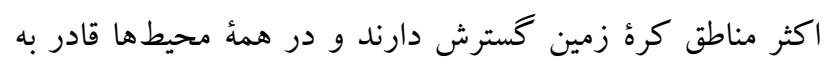

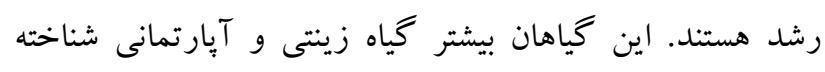

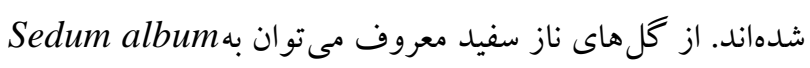
Sedum acre L. و اشاره كرد. گياه ناز سفيد Selbum كياهى علفى، گوشتدار با گل هايى به رنخك سفيد و مجتمع به

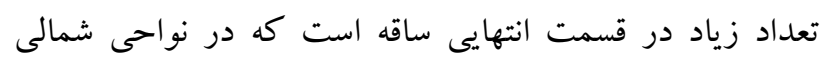

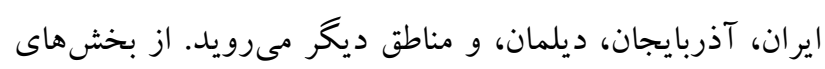


رديف بالا، بايين، جِب و راست بهمنزلهُ بلانكك بدون سلول خالى

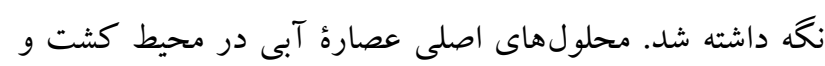

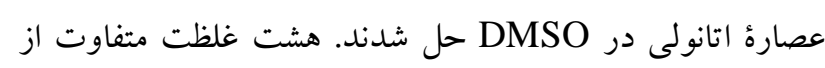

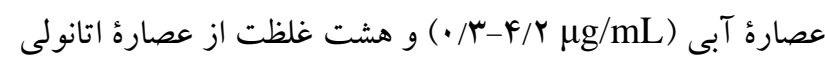

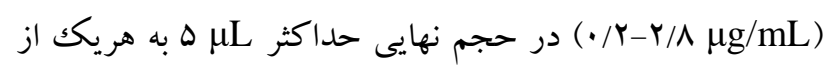

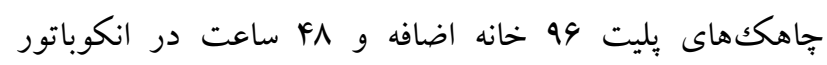
نخهدارى شد. غلظت صفر براى جاهك شاه شاهد (محيط كشت بدون عصاره) و غلظتهاى

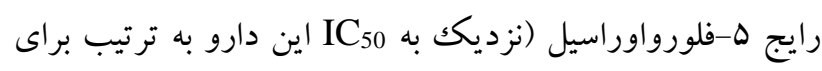

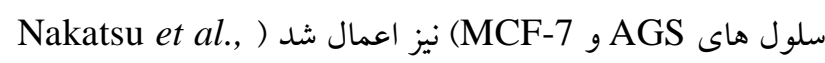
2005). سبس، با كيت (MTT) روش شر كت سازندة (Roche applied science,Germany)

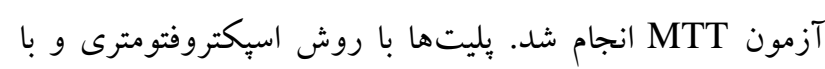

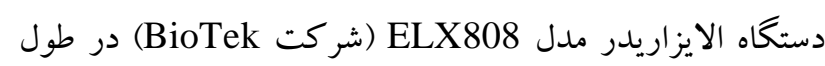

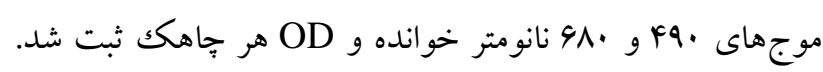

درصد سلولهاى زنده از طريق فرمول زير تخمين زده شد: درصد سلولهاى زنده = OD) 100 سلولهاى كنترل 100 سلولهاى تيمارشده)

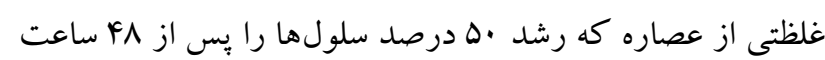

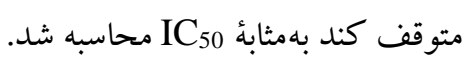
بروسى ميزان اثر عصاره كياهى بر تكثير سلول با استفاده از BrdU تعداد ينج هزار از سلولهاى AGS، MCF-7 در جهار رديف از

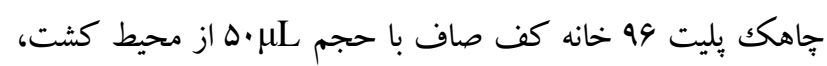

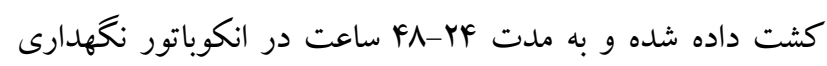

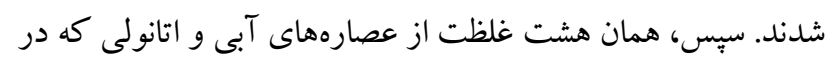

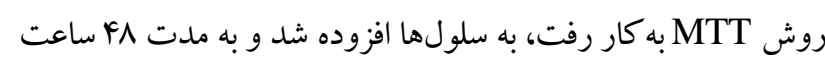

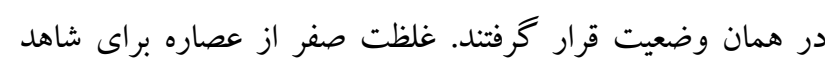

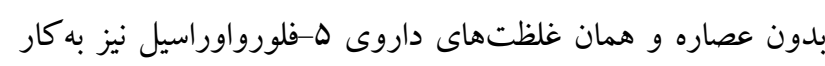
رفت. بعد از اين مدت، با استفاده از كيت Cell Proliferation (Roche طبق دستور شركت سازنده ELISA, BrdU kit ميزان مصرف Applied Science, Germany)

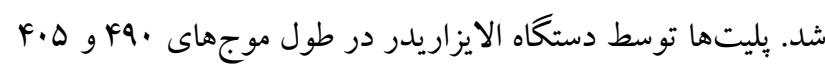

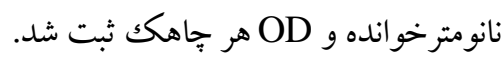

بررسى اثر عصاره در القاى مركى سلولى آيوپيتوز بهروش

TUNEL
حدود ·F Fرم از سرشاخههاى هوايى ناز سفيد با آب مقطر

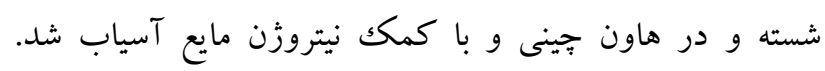

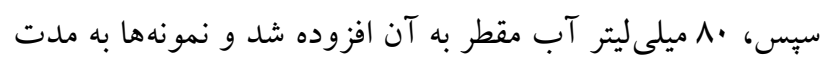

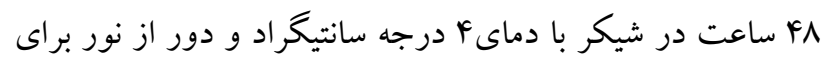

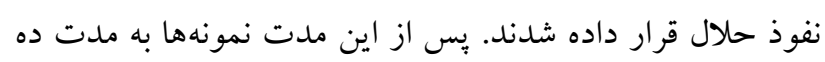

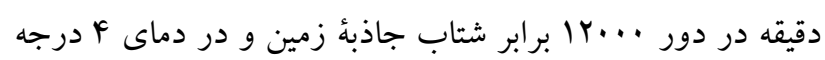

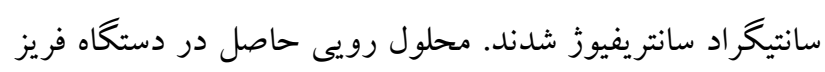
دراير بهصورت يودر خشك شد و براى استفاده در مراحل بعدى دائل

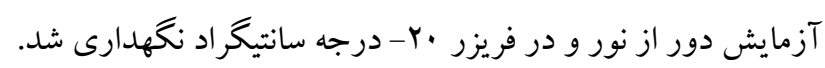
تصيئ عصارة اتانولى

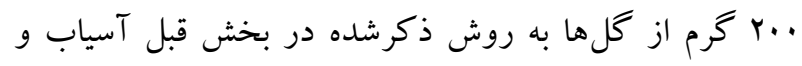

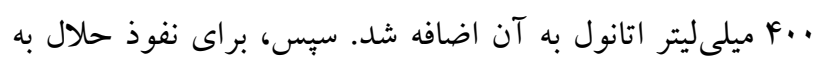

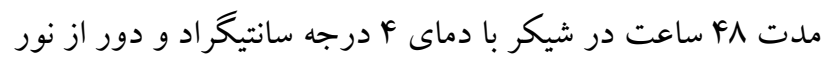

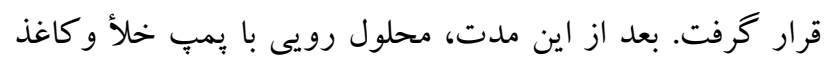

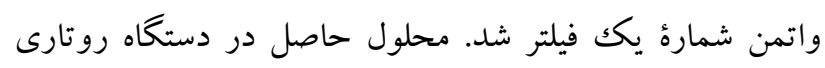

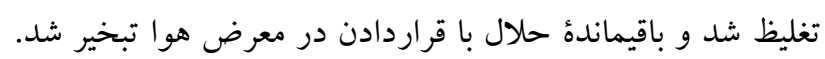

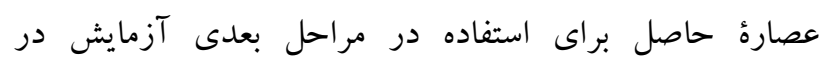

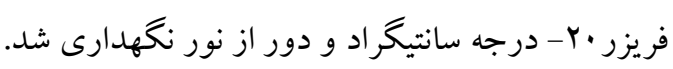

\section{تهيةُ ردههاى سلولى و كشت آنها}

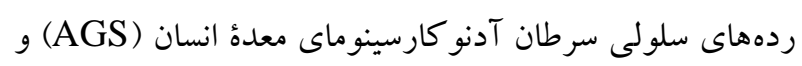

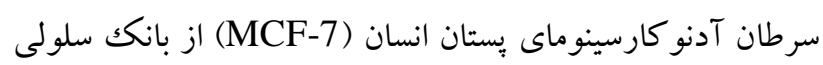

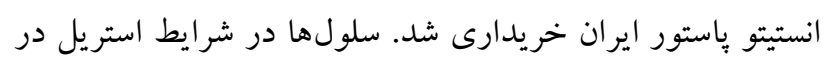

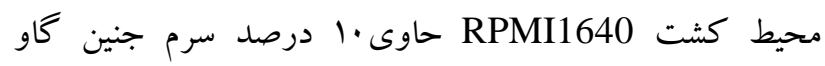

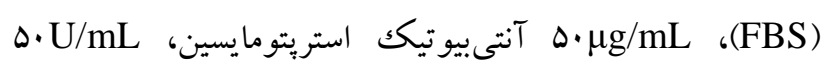

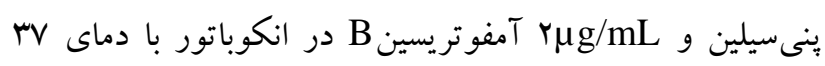

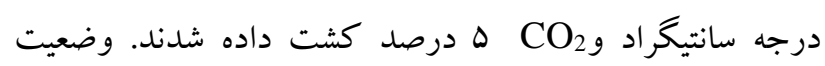

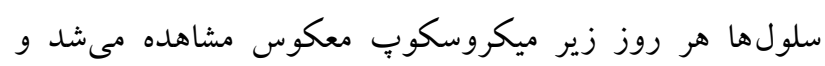

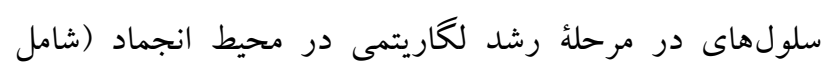

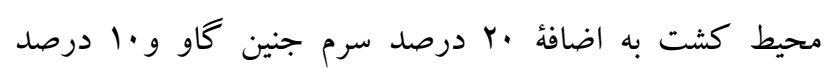
(DMSO

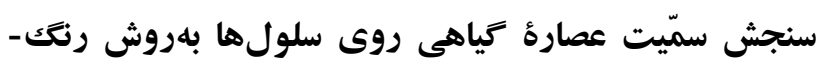
آميزى سنجي سميت

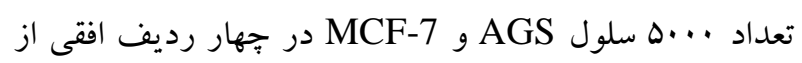

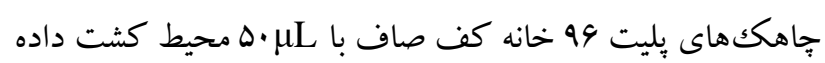
شد و به مدت MF-FA ساعت در انكوباتور با همان شرايط رشد

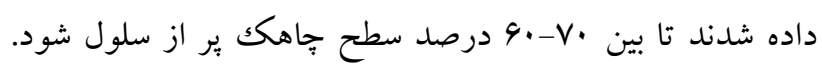


ديده نشد شامل گردشدن و جداشدن سلولها از كف ظرف و

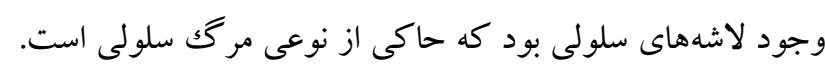

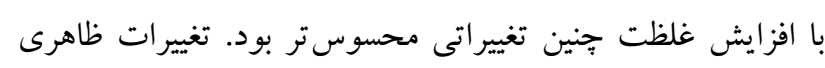

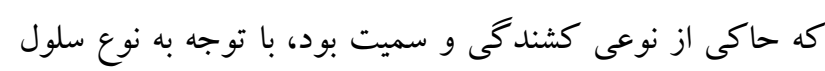

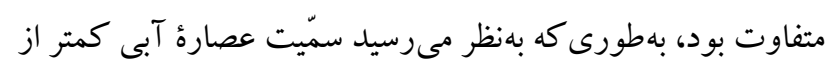

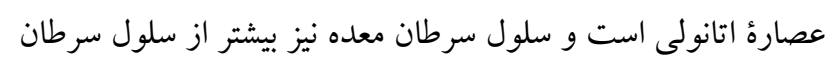

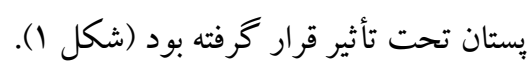

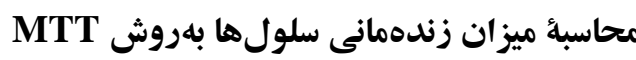

محاسبة ميزان زندهمانى سلولها بهروش

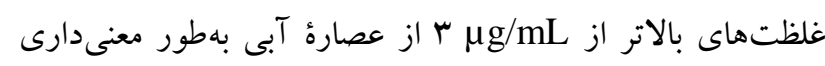
رشد سلولهاى AGS را مهار كرده بود. همين عصاره در غلظت

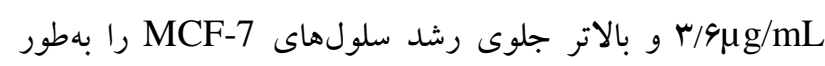

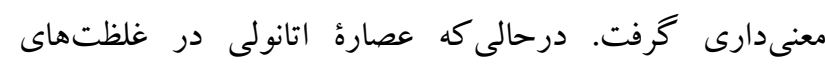

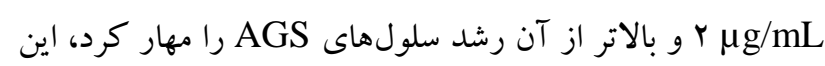

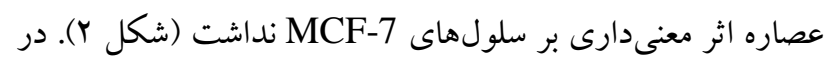

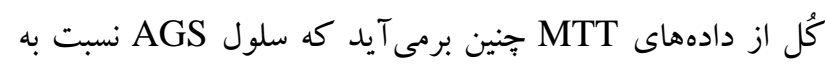

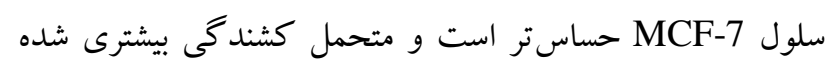

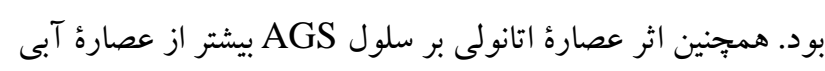

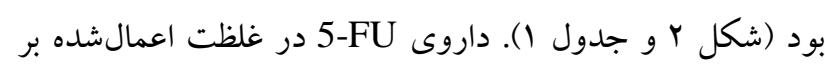

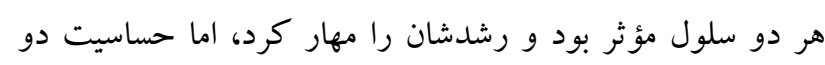

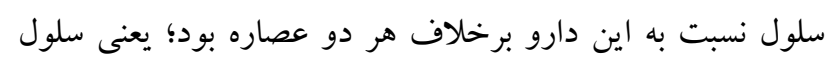

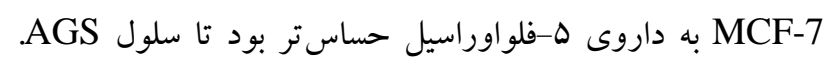
ارزش IC50 دو عصاره بر دو سلول سرطانى در جدول ا آمده است. دادههاى اين جدول نيز تأييد مى كند كه سلول

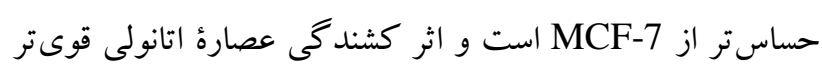
از عصارة آبى است.

نتايج ميزان اثر عصاره بر سنتز DNA با استفاده از

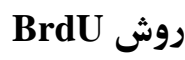
در بخش دوم ميزان تكثير سلولها بهروش اندازه BrdU

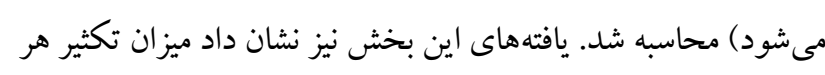

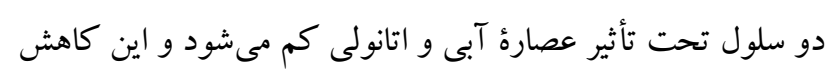

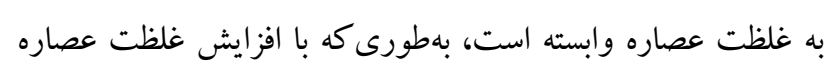

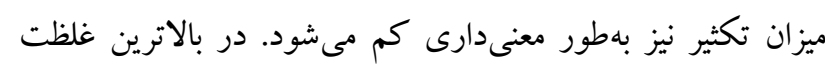

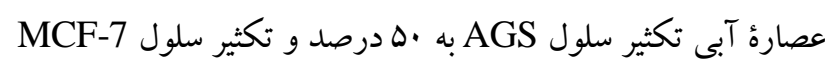

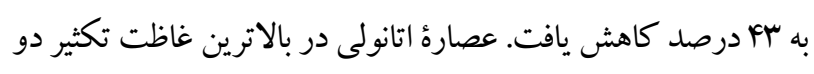

سلولهاى AGS و MCF-7 روى لامل و در بليتهاى شش خانه

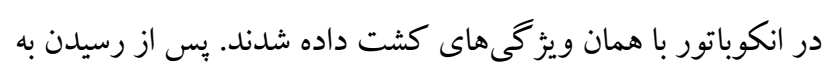

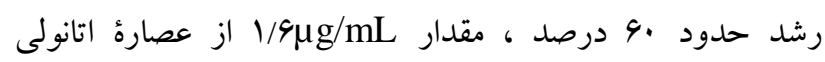
و r/F انكوباتور منتقل شدند. اين غلظت از وسط محدوده غلظتى مورد

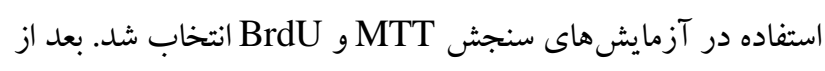

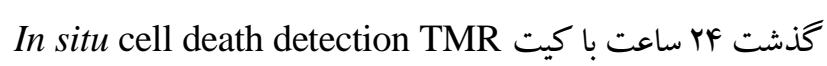
(Roche applied science, طبق دستور شركت سازنده Red

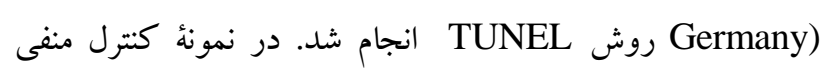
آنزيم ترمينال ترانسفراز حذف شد و در نمونهُ كنترل مثبت از آنزيم DNase I

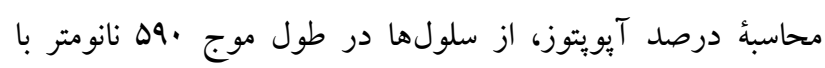

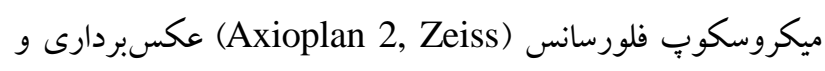

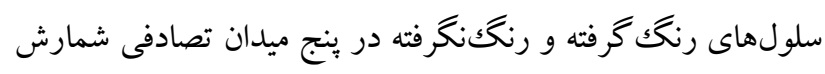

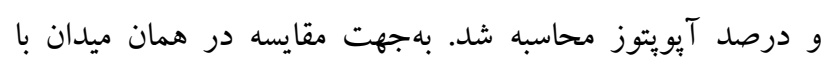
ميكروسكوٍ نورى معمولى هم از سلولها عكس بردارى شد. روشهاى آمارى

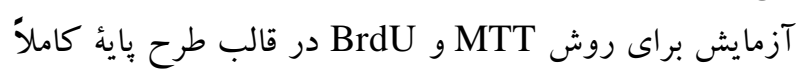

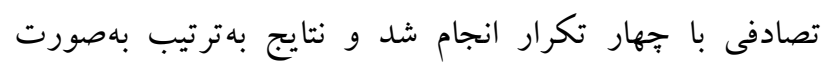

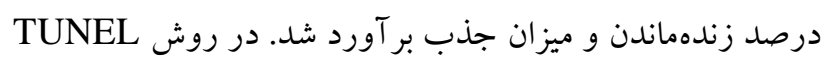

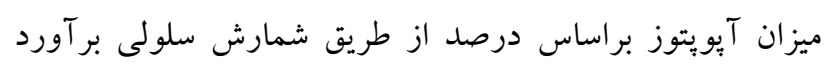

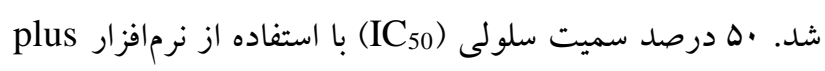
(INER,V1.0) دادههاى حاصل از اين آزمون بهصورت تجزئ واريانس

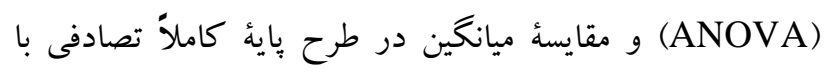

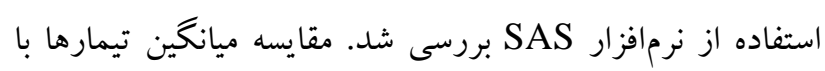

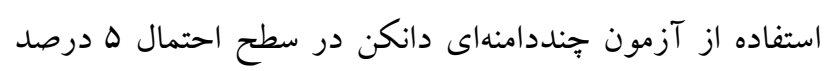

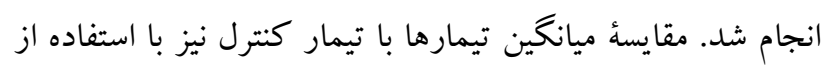
آزمون دانت در سطح احتمال \%ه تحت بررسى قرار خرفت.

\section{نتايج}

در ابتدا سلولهاى سرطان معده و يستان به مدت بم ساعت در معرض تيمار با عصارههاى آبى و اتانولى ناز سفيد قرار گرفتند.

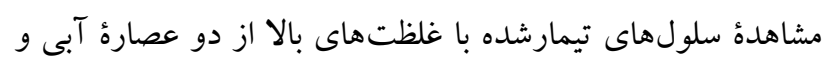

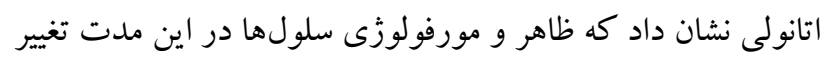
كرده است. اين تغييرات ظاهرى كه در سلولهاى گروه كنترل 

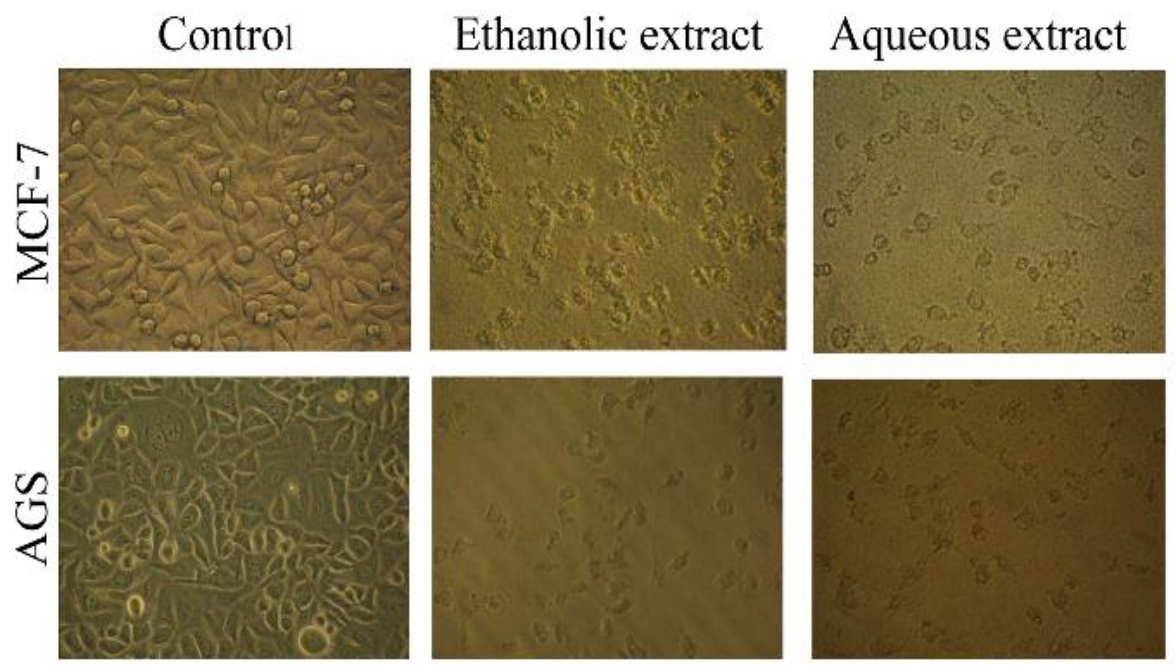

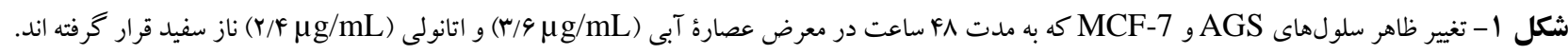

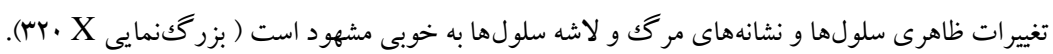

Fig. 1. Morphological changes in AGS and MCF-7 cells treated by the aqueous $(3.6 \mu \mathrm{g} / \mathrm{mL})$ and ethanolic extracts $(2.4$ $\mu \mathrm{g} / \mathrm{mL}$ ) of $S$. album for $48 \mathrm{~h}$. Some obvious alterations and signs of cell death and cell debris are evidently observable (Magnification $320 \mathrm{X}$ ).

$$
\text { جدول ا - شاخص IC دو عصارة آبى و اتانولى ناز سفيد بر سلولهاى سرطان بِتان و معدهُ انسان كه بهروش MTT بهدست آمده است. }
$$

Table 1. IC50 values of two aqueous and ethanolic extracts against human breast cancer and stomach cancer cell lines obtained by the MTT assay.

\begin{tabular}{|c|c|c|}
\hline AGS & MCF-7 & \\
\hline F/DrI & $\Delta / Y Y^{q}$ & عصارة آبى ( \\
\hline$r / 491$ & $\Delta / \Delta F q$ & عصارة اتانولى (رg/mL) \\
\hline
\end{tabular}
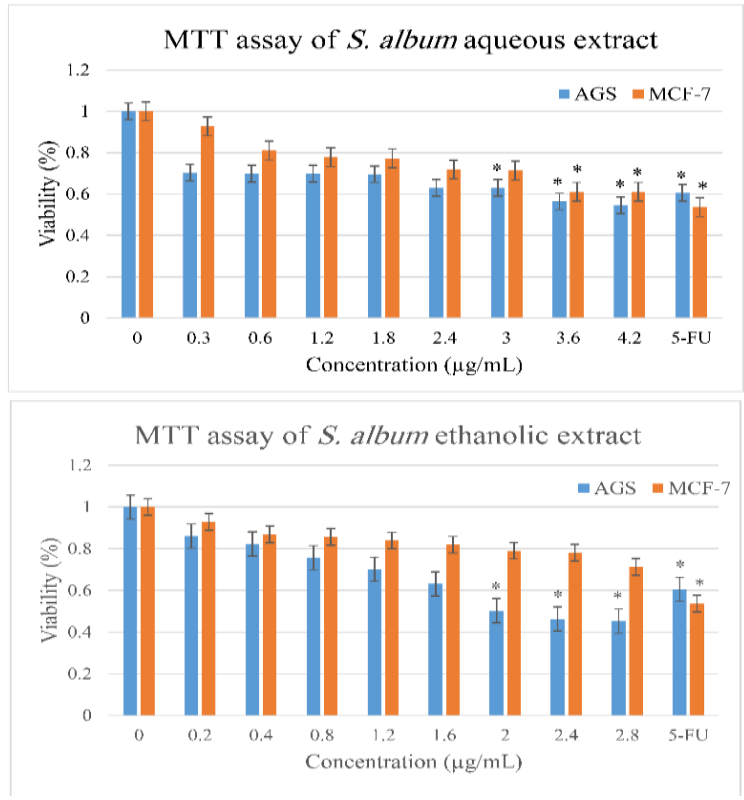

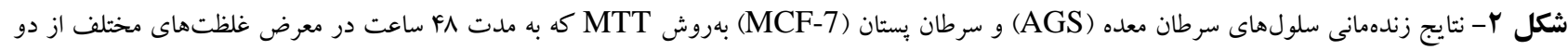

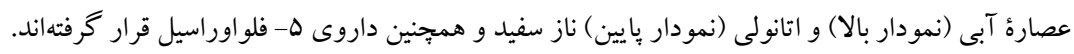

Fig. 2. The results of viability of AGS and MCF-7 cells treated by different concentrations of aqueous and ethanolic extracts of S. album and 5-FU for $48 \mathrm{~h}$ by MTT assay. 
TUNEL و BrdU ،MTT تحليل و مقايسه مى شود. سنجش به

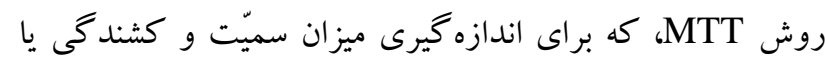

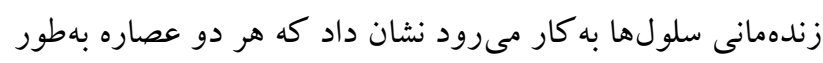

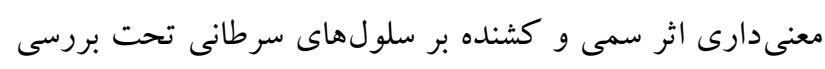

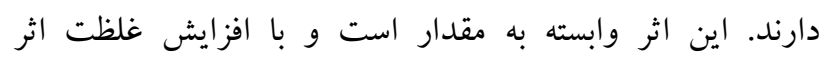

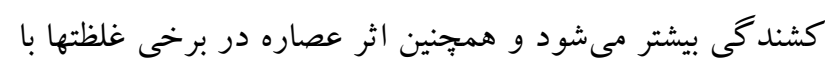

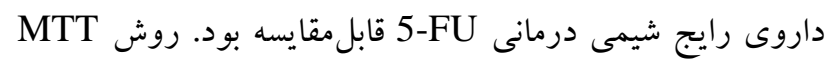

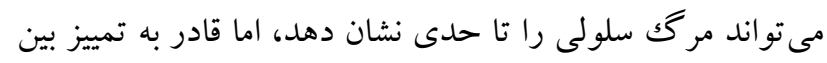

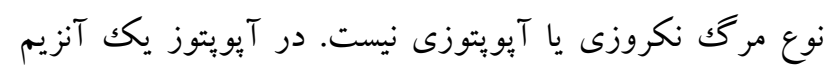

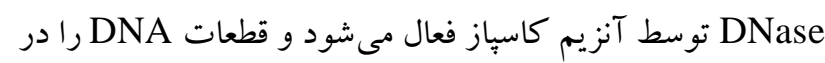

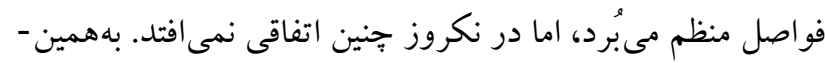

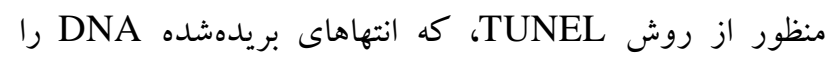
رنخك مى كند و قادر به تشخيص مر گك آيويتوزى است، استفاده

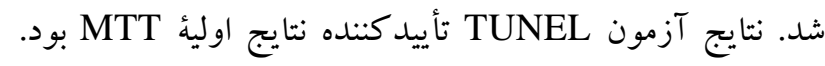
MCF-7 بهورى كه در هر دو روش سلول AGS نسبت به سلول

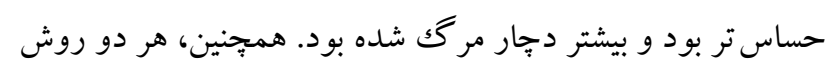

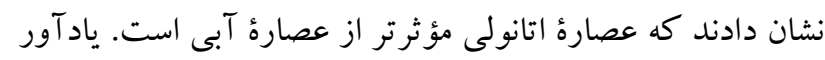
مى شود براى تعيين ميزان اثر احتمالى حلال عصارة اتانولى

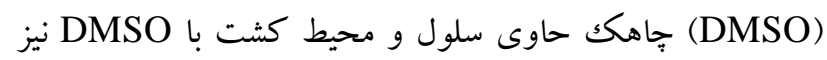
در طراحى آزمايش در نظر گرفته شد. نتايج نشان داد سميّت

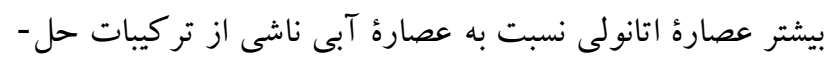
شده در آن است نه حلال (دادهها نشان داده نشده است). كياهان

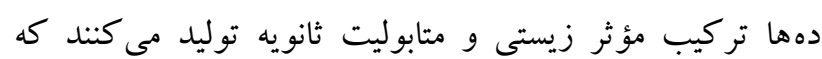

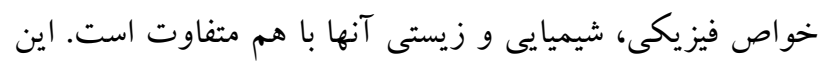

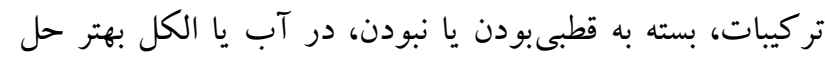

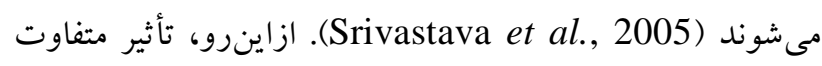

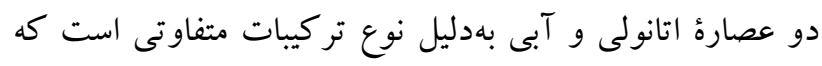

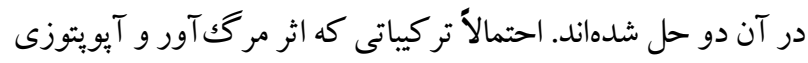
دارند بيشتر در عصارة اتانولى حل شدهاند. شناسايى شيميايى تر كيبات موجود در دو عصاره مى تواند به شناسايى علت تفاوت در

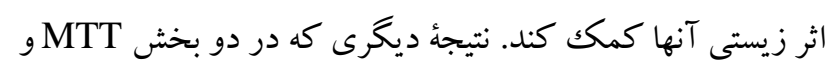

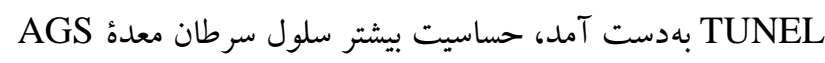

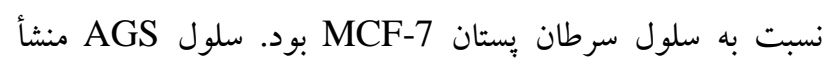

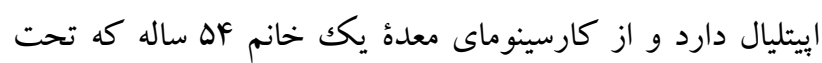

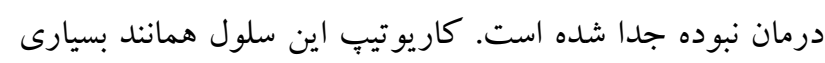
از سلولهاى سرطانى غيرعادى است (Barranco et al., 1983).
سلول AGS و MCF-7 را به ترتيب به Vل درصد و •4 درصد كاهش داد. داروى ه-فلواوراسيل تكثير دو سلول فوق را به ترتيب

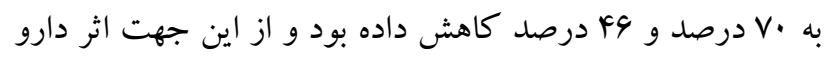

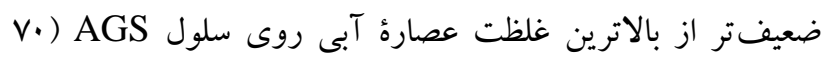

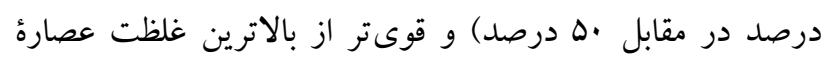

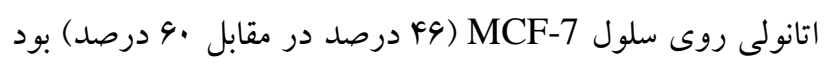

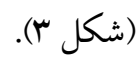
يافتهٔ جالبتوجه در اين بخش آن بود كه هر دو عصاره ميزان

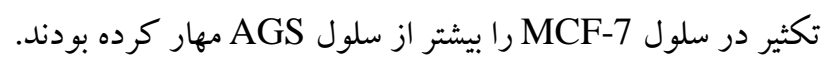
بهبارت ديخر سلول MCF-7 نسبت به سلول AGS حساس تر بود و اين برخلاف يافتههاى بخش MTT است كه در آن سلول AGS حساس تر از MCF-7 بود و ميزان زندهمانى آن تحت تأنئ بأثير عصاره-

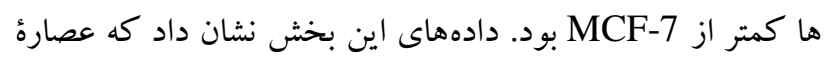

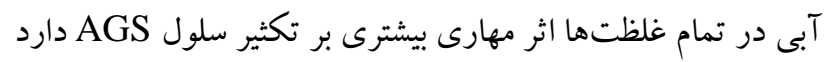

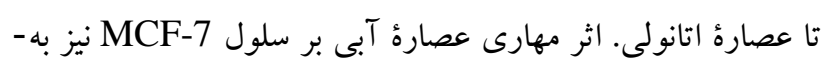

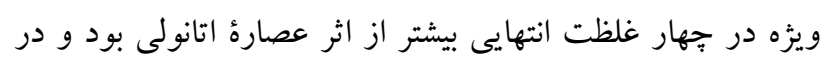

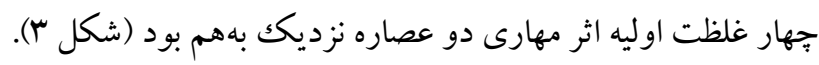
نتايج حاصل از بررسى اثر عصاره در القاء مركى سلولى TUNEL آيويتوز به روش آناهل

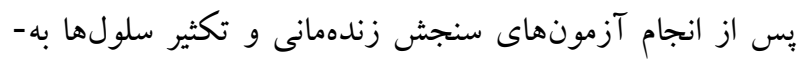

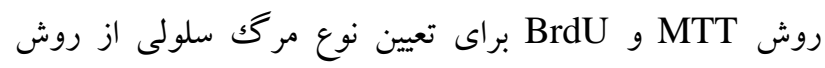

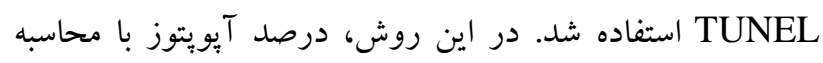

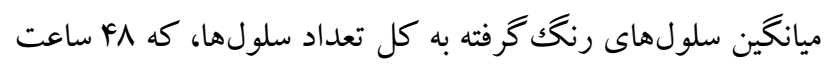

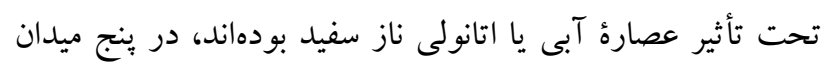

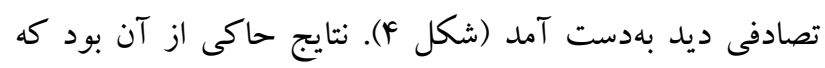
سلولهاى AGS تحت تيمار با غلظت اعصارة اتانولى ألى بg/mL ناز سفيد متحمل به درصد

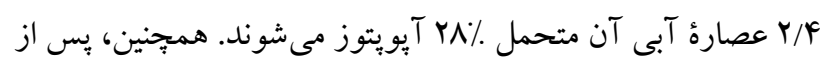

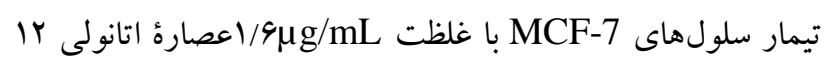
درصد آيويتوز و تيمار با غلظت r/\& درصد آيويتوز در اين سلولها مشاهده شد.

\section{بحث}

هدف تحقيق آن بود كه اثر احتمالى ضدسرطانى دو عصاره:

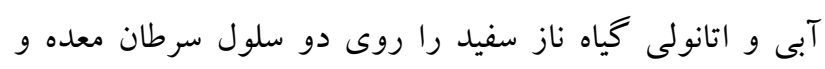

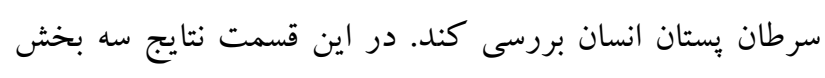




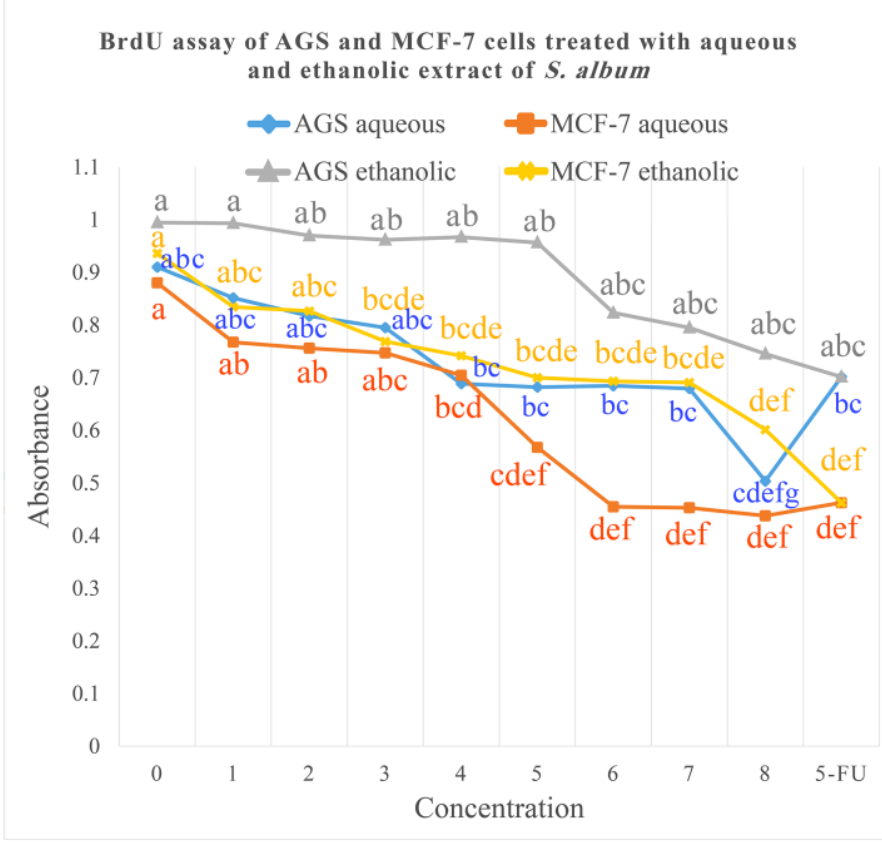

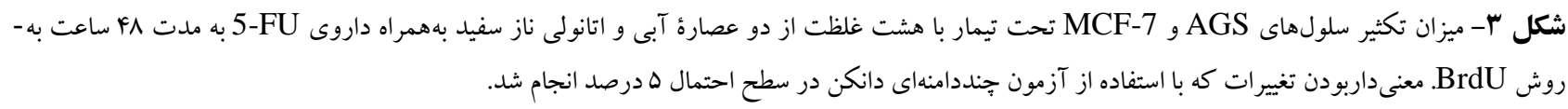

Fig. 3. The proliferation rate of AGS and MCF-7 cells under treatment by eight different concentrations of aqueous and ethanolic extracts of $S$. album together with 5-FU for $48 \mathrm{~h}$ by BrdU assay. The significance level of variations as obtained by Ducann's multiple range test was performed at $P<0.05$.

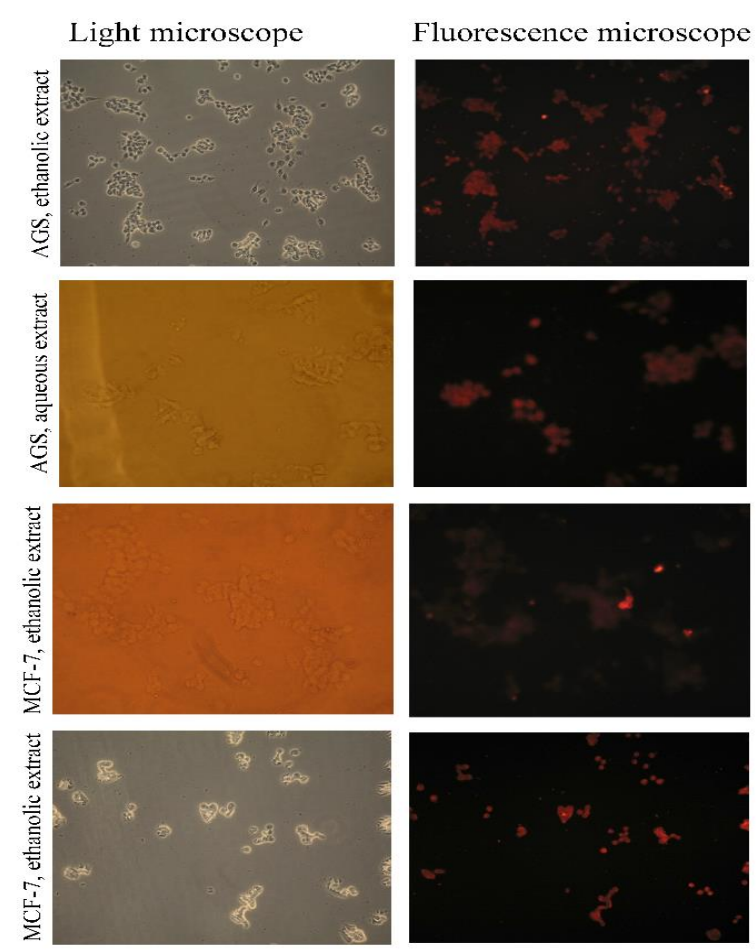

شكل f- تصوير سلولهاى AGS و MCF-7 تيمارشده با دو عصارة آبى و اتانولى ناز سفيد در روش TUNEL. سلولهاى آيويتوزى با رنغك قرمز در تصوير

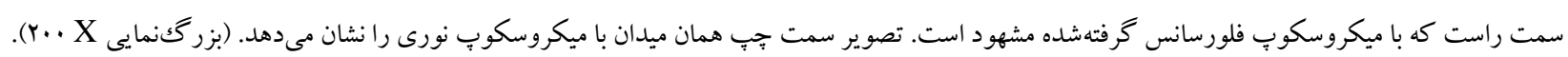

Fig. 4. The figure of AGS and MCF-7 cells treated by two aqueous and ethanolic extracts of S. album in TUNEL assay. The apoptotic red stained cells are evident in photo on the right, taken by means of fluorescence microscope. The photo on the left shows the same field by means of an optical microscope. (Magnification $200 \mathrm{X}$ ). 
شد. اينكار از طريق افزايش تعداد سلولها در مرحلة G جرخهُ

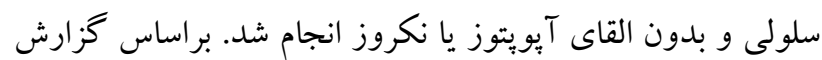

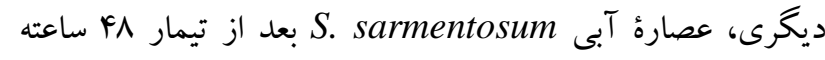

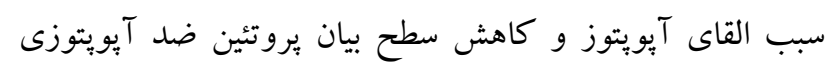
Huang در سلولهاى سرطان كبد انسان، HepG2-2

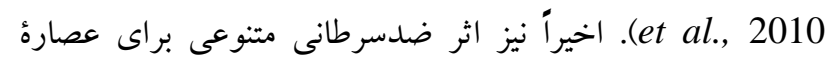
همين گياه S. sarmentosum شامل مهار رشد سلول سرطان

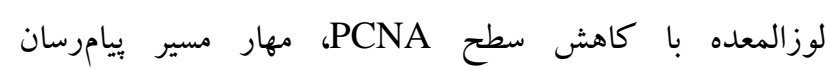

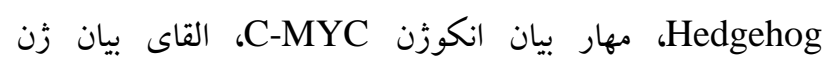
سر كوبخر تومور P53، القاى مسير داخلى آيويتوز، مهار EMT و توقف جرخ مُ سلولى در مرحلة

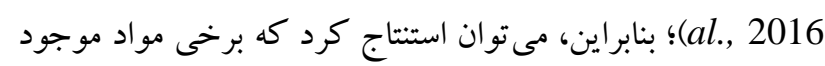

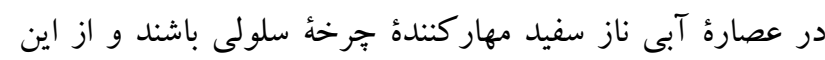

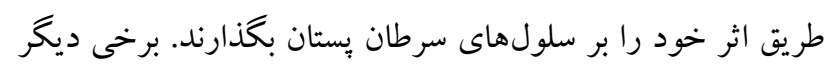

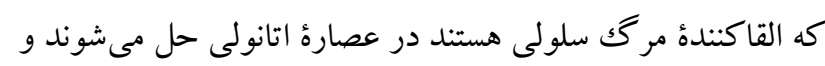

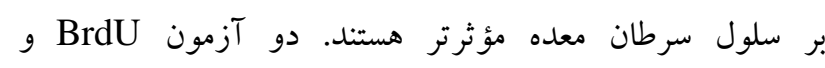
TUNEL

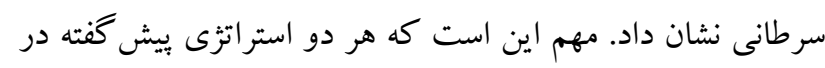

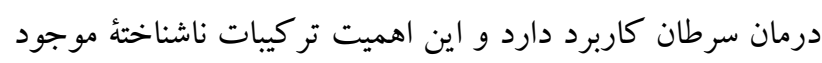
در ناز سفيد براى درمان سرطان را بيشتر نمايان مى كند.

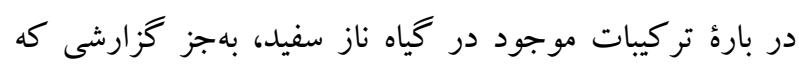

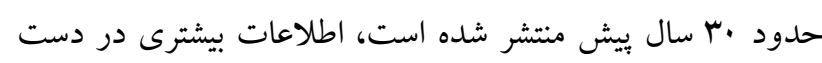

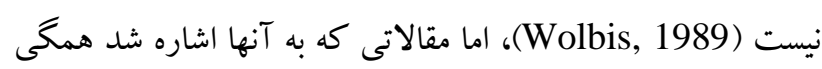
دربارة كونهُ ديخرى از همين سرده كار كردهاند كه در طب سنتى

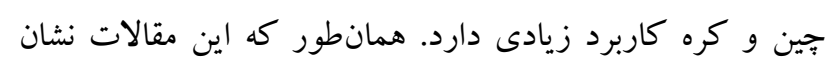

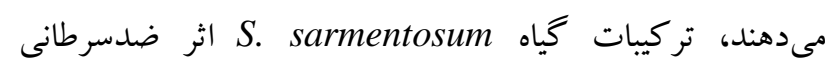
وسيعى دارند كه هم شامل مهار تكثير سلول مىشود و هم القاى

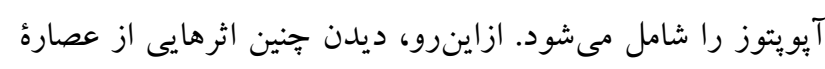

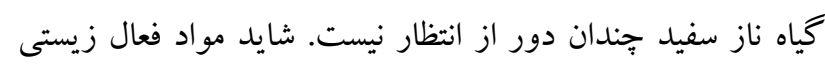

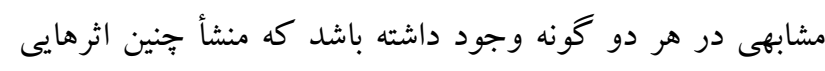

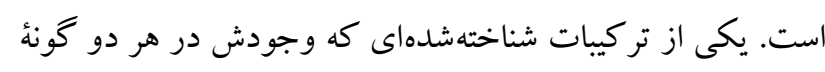
S. album و S. Sarmentosum است (Ma et al., 2017, Wolbis, 1989). كوئرستين يكك ؤر فلاوئوئيد بلىفنولى است كه در بسيارى از گياهان خوراكى و

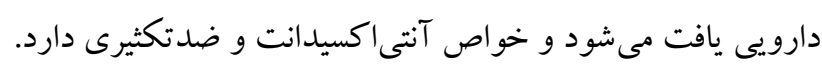

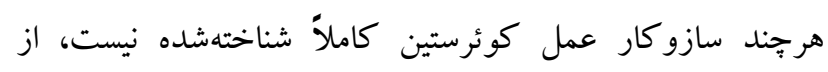

نيز يك سلول سرطان كارسينومايى با منشأ اييتليالى است MCF-7

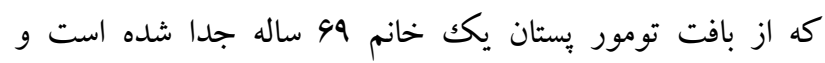

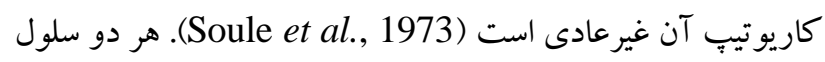
فوق منشأ بافتى مشابهى دارند، اما بايد توجه داشت كه كه مسيرهاى

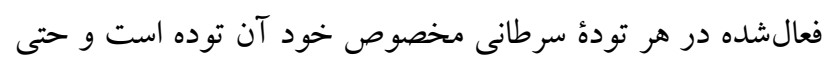

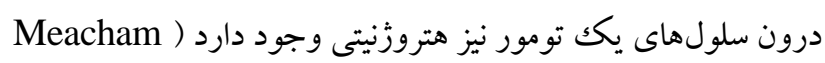

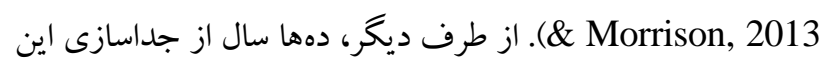

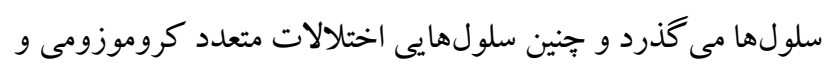
زرنتيكى دارند كه طى ساليان كذشته در اثر كشتهاى مناى متوالى بيشتر

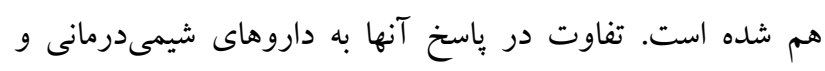

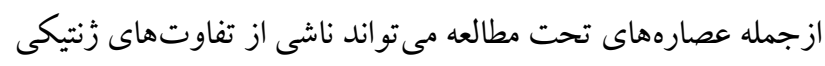

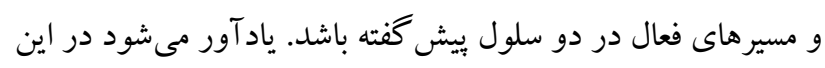
تحقيق سلول فيبروبلاست طبيعى انسان (HSkMC) نيز به موازات

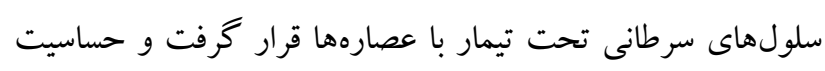
آن از هر دو سلول سرطانى كمتر بود (دادهها نشان داده نشده است). اين خود حاكى از آن است كه عصارهها بر سلول طبيعى اثر كشنده

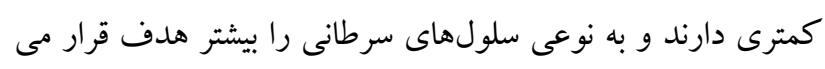
دهند. اين خود يكك مزيت كاربردى براى ادامه تحقيق درباب تر كيبات ضدسرطان اين كياه است.

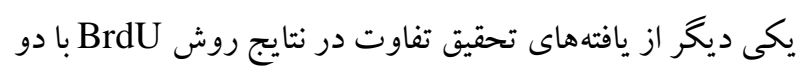
روش ديخر بود. درحالى كه دو روش MTT و MUNEL

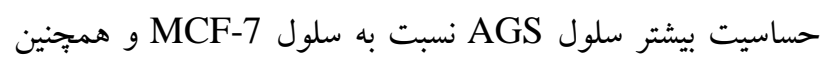

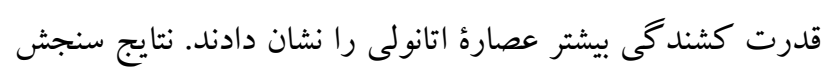
تكثير بهروش BrdU برعكس بود؛ يعنى تكثير سلول MCF-7

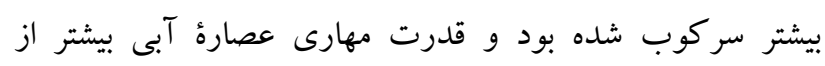

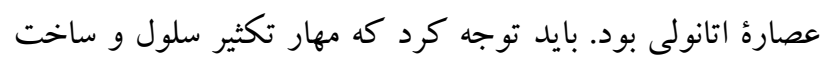
Dر فرخه سلولى، الزاماً به مركى منجر نمىشود. برخى تركيبات ممكن است جرخهُ سلولى را در مرحلة

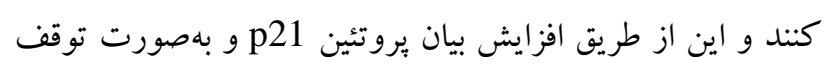

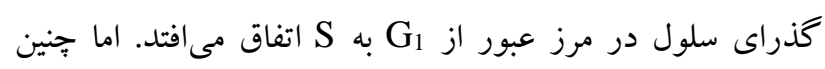

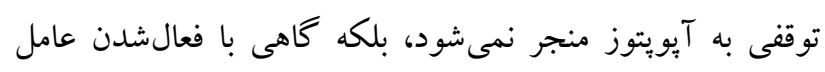

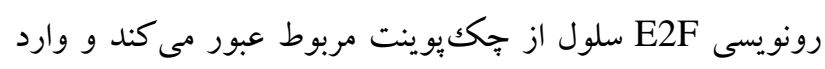
مرحلة S مىشود. Sang و همكاران (2000) يافتهُ مشابهى داشتند. آنان گزارش كردند كه آلكالو

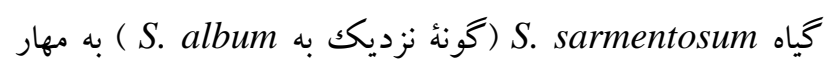
تكثير جرخه سلولى در سلولهاى سرطان كبد انسان و موش منتهى نز 
باغ گياهناسى نوشهر براى همكارى در نمونهبردارى و تأييد ناز سفيد تشكر مى كنند.

\section{REFERENCES}

Atanasov, A.G., Waltenberger, B., Pferschy-Wenzig, E.M., Linder, T., Wawrosch, C., Uhrin, P., Temml, V., Wang, L., Schwaiger, S., Heiss, E.H., Rollinger, J.M., Schuster, D., Breuss, J.M., Bochkov, V., Mihovilovic, M.D., Kopp, B., Bauer, R., Dirsch ,V.M. and Stuppner, H. 2015. Discovery and resupply of pharmacologically active plant-derived natural products: A review. Biotechnol Adv. 33: 1582-1614.

Bai, Y., Chen, B., Hong, W., Liang, Y., Zhou, M. and Zhou, L. 2016. Sedum sarmentosum bunge extract induces apoptosis and inhibits proliferation in pancreatic cancer cells via the hedgehog signaling pathway. - Oncol. Rep. 35: 2775-2784.

Barranco, S., Townsend, C., Casartelli, C., Macik, B., Broerwinkle, W. and Gourley, W. 1983. Establishment and characterization of an in vitro model system for human adenocarcinoma of the stomach. - Cancer Res. 43: 1703-1709.

Huang, D., Zhang, W., Huang, D. and Wu, J. 2010. Antitumor activity of the aqueous extract from sedum sarmentosum bunge in vitro. - Cancer Biother. Radiopharm. 25: 81-88.

Jung, H. J., Kang, H. J., Song, Y. S., Park, E. H., Kim, Y. M. and Lim, C. J. 2008. Anti-inflammatory, anti-angiogenic and anti-nociceptive activities of sedum sarmentosum extract. - J. Ethnopharmacol. 116: 138-143.

Kang, T. H., Pae, H.O., Yoo, J. C., Kim, N.Y ,.Kim, Y. C., Ko, G.I. and Chung, H.T. 2000. Antiproliferative effects of alkaloids from sedum sarmentosum on murine and human hepatoma cell lines. - J. Ethnopharmacol. 70: 177-182.

Kashyap, D., Mittal, S., Sak, K., Singhal, P. and Tuli, H. S. 2016. Molecular mechanisms of action of quercetin in cancer: recent advances. - Tumour Biol. 37: 12927-12939.

Ma, G., Yang, C., Qu, Y., Wei, H., Zhang, T. and Zhang, N. 2007. The flavonoid component isorhamnetin in vitro inhibits proliferation and induces apoptosis in eca-109 cells. - Chem. Biol. Interact. 167: 153-160.

Ma, X., Yang, J., Deng, S., Huang, M., Zheng, S., Xu, S., Cai, J., Yang, X. and Ai, H. 2017. Two new megastigmanes from chinese traditional medicinal plant sedum sarmentosum. - Nat. Prod. Res. 31: 1473-1477.

Meacham, C.E. and Morrison, S.J. 2013. Tumor heterogeneity and cancer cell plasticity. - Nature 501: 328-337.

Nakatsu, N., Yoshida, Y., Yamazaki, K., Nakamura, T., Dan, S., Fukui, Y. and Yamori, T. 2005. Chemosensitivity profile of cancer cell lines and identification of genes determining chemosensitivity by an integrated bioinformatical approach using cdna arrays. - Mol. Cancer Ther. 4: 399-412.
اثرهاى ضدسرطانى كوئرستين مى توان به كاهش بيان P53 جهش -

يافته، كاهش بيان انكوزن ras، توقف جرخهُ سلولى در مرحلة القاى آيويتوز، مهار رگكزايى و متاستاز، اثر سمزدايى و ضدالتهابى اشاره كرد (Kashyap et al., 2016). اثر ضدسرطانى ناز سفيد كه در اين تحقيق مشاهده شد ممكن است ناشى از وجود كوئرستين يا تركيبات مشابه باشد. براى ايزورامنتين نيز، كه فرم متيله كوئرستين است و در خياه ناز سفيد ديده شده است، اثرهاى ضدسرطانى مشابهى همجون ممانعت از تكثير سلول و القاى آيويتوز در سلول سرطان مرى انسان خزارش شده است ( Ma et

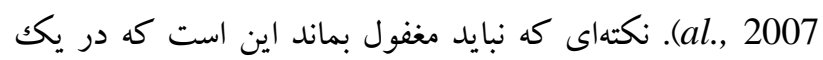
عصاره خام دهها تركيب ناشناخته وجود دارد كه برخى از آنها اثر مشابه دارند و بين اين تركيات همكارى سينرزى وجود دارد. همجنين، يك تركيب منفرد مثل كوئرستين اثرهاى متنوع زيادى دارد كه به برخى از آنها اشاره شد. ازهمينرو است كه كاهي منى اوقات اثر عصاره از يكك داروى رايج شيمىدرمانى قوىتر ظاهر مى شود.

\section{نتيجاه كيرى}

دادههاى اين بزوهش درمجموع اثرهاى ضدسرطانى گياه ناز سفيد را بر دو سلول سرطان معده و سرطان يستان انسان نشان داد.

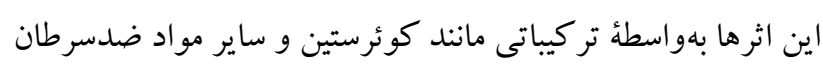
ناشناخته و از طريق مهار جر خهُ سلولى يا از طريق القاى آيويتوز انجام مىشوند. متأسفانه، اطلاعات ما در مورد تركيبات ناز سفيد اندكك است و اين تحقيق جزو اولين كارهايى بود كه در ايران درباره اين كياه انجام شد. با توجه به بومىبودن ناز سفيد، مطالعات بيشتر درباره خواص دارويى آن و شناسايى و جداسازى تركيباتى كه مولكولها و مسيرهاى زيستى فعال در سرطان را هدف قرار

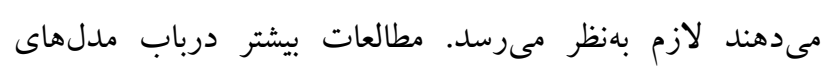
حيوانى سرطان در موش نيز مى تواند خواص ضدسرطانى اين گياه را روشن كند.

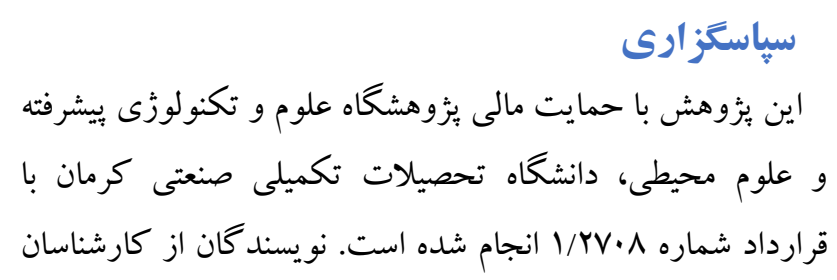


Newman, D. J. and Cragg, G. M. 2016. Natural products as sources of new drugs from 1981 to 2014 . - J. Nat. Prod. 79: 629-661.

Ouyang, L ., Luo, Y., Tian, M., Zhang, S. Y., Lu, R., Wang, J. H., Kasimu, R. and Li, X. 2014. Plant natural products: from traditional compounds to new emerging drugs in cancer therapy. - Cell Prolif. 47: 506-515

Soule, H., Vasquez, J., Long, A., Albert, S. and Brennan, M. 1973. A human cell line from a pleural effusion derived from a breast carcinoma. - J. Natl. Cancer Inst. 51: 1409-1416.

Srivastava, V., Negi, A. S., Kumar, J. K., Gupta, M. M. and Khanuja, S. P. 2005. Plant-based anticancer molecules: a chemical and biological profile of some important leads. - Bioorg Med. Chem. 13: 5892-5908.
Tariq, A., Sadia, S., Pan, K., Ullah, I., Mussarat, S., Sun, F., Abiodun, O. O., Batbaatar, A., Li, Z., Song, D., Xiong, Q., Ullah, R., Khan, S., Basnet, B. B., Kumar, B., Islam, R. and Adnan, M. 2017. A systematic review on ethnomedicines of anti-cancer plants. Phytother Res. 31: 202-264.

WHO. 2014. Global status report on noncommunicable diseases. In: MENDIS, H. (Ed.). Geneva: World Health Organization.

Wolbis, M. 1989. Flavonol glycosides from sedum album. - Phytochem. 28: 2187-2189.

Zhou, Y., Zheng, J., Li, Y., Xu, D. P., Li, S., Chen, Y. M. and Li, H.B. 2016. Natural polyphenols for prevention and treatment of cancer. - Nutrients 8: 515 .

How to cite this article:

Meimandi. K. and Yaghoobi, M.M. 2019. The Effect of aqueous and ethanolic extracts of Sedum album L. on human stomach and breast carcinoma cell lines in vitro. - Nova Biol. Reperta 6:.10-19.

ميمندى، كى. و يعقوبى، م.م. هوبا. اثر عصارههاى آبى و اتانولى ناز سفيد بر سلولهاى سرطان معده و سرطان بِّتان انسان در شيشه. - يافتهاى نوين در علوم 